\title{
The Impact of Environmental Taxes on Agriculture - the Case of Slovakia
}

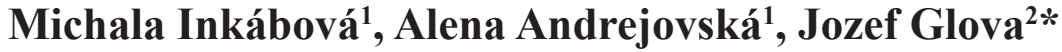 \\ ${ }^{1}$ Department of Finance, Technical University of Košice, Slovakia \\ ${ }^{2}$ Department of Banking and Investment, Technical University of Košice, Slovakia
}

Received: 3 August 2020

Accepted: 21 November 2020

\begin{abstract}
Environmental protection is one of Europe's key values. The agricultural sector performance depends on the tax system that affects the profitability. The aim of this paper is to identify and quantify the impact of environmental instruments on the production and financial situation of the Slovak agriculture, which is expressed through the output/input and ROE indicators. The national database of Slovak agriculture provided by Radela company and environmental indicators based on Eurostat and Farm Accountancy Data Network (FADN) databases, time period 2009-2018 were examined. The used research methods were multiple regression analysis, correlation coefficient and cluster analysis. The paper defined main hypothesis, that production and financial indicators were dependent on the same variables. The results of the analysis confirmed the statistical significance of energy tax. If the percentage of energy tax in agriculture increase by $1 \%$ production would decrease by 0.01458 with a probability of $95 \%$ and ROE indicator would decrease by 2.375 with a probability of $99 \%$. The results of the analysis confirmed stated hypothesis. The second part of the analysis deals with the hierarchical clustering. The position of Slovak agriculture across EU Member States based on two time periods 2009 and 2018 changed according the settlement of fiscal instruments.
\end{abstract}

Keywords: environmental indicators, production indicator, return on equity ROE, regression analysis, dendrogram

\section{Introduction}

The concept of environmental taxes has several meanings and can be interpreted in different ways. The term is often used to refer to taxes with an environmental, rather than a fiscal motivation, promoting protection of the environment and natural

*e-mail: jozef.glova@tuke.sk resources. Environmental taxes are key instruments for achieving sustainability in the economy, by increasing the prices of environmentally harmful goods or the prices of production inputs [1-4]. The definition used and provided by Eurostat describes the tax as a tax whose tax base is a physical unit or a proxy of a physical unit of something that has a proven, specific negative impact on the environment, and which is identified in the European System of Integrated Economic Accounts.

Conventional economic theory suggests that increasing the price of normal goods and services through the use of a tax reduces its own demand [3, 4]. 
The main problem in the determination of the economy-wide effects of environmental taxation or other related policies is the high complexity involved in modern economic systems and societies. The most important ones are: macro-econometric models, inputoutput methods and applied general equilibrium methods $[5,6]$.

Computable general equilibrium modelling is an open standard tool for the analysis of the economywide impacts of environmental policies, including environmental tax issues, on resource allocation and the associated implications for incomes of different economic agents. They come from traditional inputoutput models. Input-output models contain a simple representation of the interchanges between industries and other economic agents in a region during a specific temporal period. A methodology based on input-output tables that related economic and environmental variables in order to offer more policy alternatives was proposed. Similar input-output approach for environmental policy was used.

The traditional view among economists and managers concerning environmental protection is that it comes at an additional cost imposed on firms, which may erode their global competitiveness. Environmental regulations force firms to allocate some inputs (labour, capital) to pollution reduction, which is unproductive from a business perspective. Technological standards restrict the choice of technologies or inputs in the production process. Taxes and tradable permits charge firms for their emissions pollution, a by-product of the production process that was free before. This traditional paradigm was challenged. Based on case studies, the authors suggest that pollution is often a waste of resources and that a reduction in pollution may lead to an improvement in the productivity with which resources are used.

The main empirical work on environmental taxation and economic growth has centred around the use of simulations on the impact on environment, use of natural resources and the whole economy.

The simulation studies concerning green tax reform and employment double dividend in European and NonEuropean countries. The double dividend hypothesis of green tax reform is an extensively researched topic that considers the possibility of producing additional economic benefits using environmentally beneficial tax measures. Both green tax reform and the double dividend postulate that the existing tax regime and environmental policies are not optimal and there is room for improvement. The government's tax revenue recycling is at the heart of any policy aimed to achieve double dividends through green tax reform [7-9].

Effective implementation of 'green' taxes requires careful consideration of a number of factors. The analysis [10] focused on the impact of environmental tax policy on sustainable development of the EU economics. Poorly designed taxes can have a reduced environmental effect and higher economic costs. The study used the Data Envelopment Analysis methodology, which allows making a comparative analysis of the relative effectiveness of ecological tax policy.

The introduction of a policy instrument is associated with costs to the national government for design and negotiation with different political parties and interest groups. Depending on the chosen instrument, it will also give rise to costs or revenues to farmers. The most common agro-environmental policy instruments in the EU are command-and-control and subsidies, while taxes are seldom applied. Subsidies to abatement activities have a positive effect on farmer income, while regulations without an accompanying subsidy imply a cost. Subsidies generate a cost to the government, while regulations can generate costs through their effect on farmers' production costs and, hence, competitiveness. Economic instruments such as taxes and subsidies are typically favoured by economists, as targets can be met at a lower cost to society as a whole. At the same time, regulations can be favoured by politicians who are concerned about fairness across income groups and for the higher political feasibility [11-13].

The hypothesis that implementation is determined by the resources available in society, institutional capacity, the choice of policy instrument and the characteristics of the abatement measure was defined. If the income is higher, more resources can be devoted to monitoring and enforcing policies. A higher institutional capacity implies that the organization of monitoring and enforcement could work better. In both cases, a higher level of enforcement can be expected [14].

The reforms enacted in the eight nations to adopt such environmental tax reforms (Denmark, Finland, Germany, Italy, the Netherlands, Norway, Sweden, and the United Kingdom) and other nations that have announced that they will adopt such reforms or have adopted elements of such reforms (Austria and Belgium), were also described. European countries have enacted many environmental taxes that do not fall within the definition of explicit environmental tax reform because the revenues from those taxes are not recycled to the economy through reductions in other taxes. If these are included, the magnitude of environmental taxes as a percentage of total tax revenues or of GDP is actually quite substantial. For instance, in the Netherlands, the revenue from all green taxes together constituted over $9 \%$ of total tax revenues in 1997 , but the revenue of only a few of those taxes $-0.5 \%$ of total tax revenues is explicitly recycled through the reduction of taxes on labour or capital [15].

Ecological tax reform in Germany was studied by researchers. Combining environmental with employment objectives, ecological tax reform envisages a double dividend. The research was based on qualitative social research methods. Attitudes appear influenced by more fundamental convictions such as economic interest or altruistic views. In contrast, ecological tax appears to politicise common people. Data show that the linking of environmental and employment objectives is not 
understood and not welcomed. In order to increase social acceptance, the paper discusses refocusing tax on environmental objectives, modestly increasing the share of ecological tax revenues spent for environmental purposes, removing inconsistencies in the ecological tax reform design, and improving information policy [16].

The community of farmers is not homogeneous and consists of the rich and the poor, large and small scale, young and old farmers that are prone to applying new ideas and keeping the old methods. It shows that the problems are not homogeneous as well, therefore there is no single applicable solution and single strategy. However, inadequate political and taxation solutions adopted in countries predict an uncertain future for the rural communities and family farms.

The singularity of sustainable taxation in agriculture was also analysed. The functions of agricultural sector include three dimensions (economic, social, environmental), which are closely connected with the conception of sustainable development. The theoretical aspect of the specificity of agricultural business in the context of taxation and singularity of sustainable taxation, systemic analysis and synthesis of theoretical insights of foreign and local scientific literature as well as the methods of induction and deduction were investigated. Theoretical research results helped to identify singularity of sustainable taxation in agriculture, which encompasses three dimensions (economic, social, environmental) with different characteristics [17].

The agricultural activity can be distinguished by its singularity that is determined by the seasonality of works, government regulations, work with biological assets and the dependence on environmental conditions. Therefore, due to the specifics of agriculture, different means of taxation are applied. The role of the agricultural sector is significant in meeting the needs of the society and implementing the government policy. In order to reach the aims of the government and common agricultural policy, it is essential to focus on the development of the competitiveness and sustainability of the agricultural sector by applying various means. With the purpose of establishing sustainable taxation for the agricultural sector, it is essential to take into account its singularity and the main principles of sustainability. Distinguished dimensions of sustainable taxation system (economic, social, environmental) correspond to the functions of the agricultural sector (food function, social function, economic situation on country growth function, environmental function) [17, $18]$.

The agricultural sector stands in contrast to the industrial and service sectors thus, the taxation systems applied to agricultural business differ from those applied to other businesses. Therefore, in order to reach the economic growth of agriculture, effective policies should be applied that stimulate agriculture. According to the existing agricultural policy of the European
Union and the new policy that will be implemented after 2020 economic questions are essential and the agricultural sector is viewed as a strategic sector, which ought to keep contributing to the growth of the European economy. Researchers stated that the taxation of agricultural business has to be different, as in this way it could have a positive impact on the economy of the country [19-21].

To create a sustainable tax reform, it is necessary to manage the whole taxation system. The management of the whole taxation system involves a systemic attitude towards tax reform, political, administrative and private sector infrastructure, its consistent growth, compliance with the changing needs of the society. This would allow the system to function and eventually become sustainable. The economic dimension of sustainable taxation system is oriented towards the economic growth, to which the agricultural business as well as stability and survival of agricultural business contribute greatly. Environmental dimension of taxation system emphasises four aspects which are important in the taxation of agricultural business, namely, protection of biodiversity and natural resources, fight against pollution and climate change.

According to research, a modern and practical framework for analyzing and assessing the system of governance of agrarian sustainability was suggested $[22,23]$. New Institutional Economics framework is incorporated and agrarian sustainability property defined, principle mechanisms and modes of governance (institutions, market, private, public, hybrid) of agrarian sustainability classified, and a holistic approach for identifying components and factors, assessing efficiency, and improving the system of governance presented. Suggested framework is to be further discussed and improved while its application requires new type of micro and macro-economic data for agrarian agents' preferences and behaviour, activities and efficiency of farming organizations, effects and impacts on social, community and natural environment.

The literature review was provided in order to assess the role of Common Agricultural Policy for more sustainable and healthier food systems in Europe, and investigated that, the European Union agri-food sector is among the major drivers of negative environmental externalities. The sector accounts for more than $10 \%$ of the total greenhouse gas emissions in the EU 28, it is among the major contributors to water and soil depletion, as well as biodiversity loss [24-27].

CAPRI stands for Common Agricultural Policy Regional Impact. The model was developed from the late 1990s onwards, primarily by a team at the University of Bonn with funding from the EU. The main rationale of the model is to forecast the consequences of changes in the EU Common Agricultural Policy: effects on the farm economy, on overall welfare, public expenditure, markets for food and agricultural inputs, land use, and on the environment. These effects are modelled at the level of regions within countries. 
The policy shock simulated [28], with the model CAPRI, which is a partial equilibrium model for the European agricultural sector. The model consists of a supply module and a market module. The supply module comprises around 280 regional farm models (one farm model for each NUTS2 region in the EU27, Norway, Western Balkans and Turkey) covering about 50 crop and animal activities for each of the regions and including about 50 inputs and outputs.

A methodological approach [29, 30] illustrated for evaluating the consequences of adopting an Environmental Tax Reform in European countries. The paper presented a multiple step approach for investigating on the Environmental Tax Reform and its effects at European level, based on aggregated, disaggregated analyses and quantitative SWOT analysis between 2000 and 2008. The results represent a basis on which to build a SWOT analysis and investigating on common issues to different territorial areas. Results suggested possible development paths based on the possibility to foster the strength, reducing or eliminating the weaknesses (lack of R\&D, low level of employment, low environmental quality), following the opportunities represented by environmental related fiscal policies with strong spillovers in other sectors.

A decomposition analysis was used to identify the main drivers of variations in the environmental taxes revenues collected by 25 European countries. By using the Index Decomposition Technique, paper analysed the main drivers that influenced the variations in the environmental taxes revenues for the time period 2004-2016. The decomposition technique was used to identify the main factors responsible for the variations of the environmental tax revenues collected in 25 European countries for the time period 2004-2016. The tax intensity effects, the structural change effect and the economic activity growth effect were factors considered in the decomposition. The main results show just 5 of the 25 Member States have moved toward a more sustainable system. In particular, Italy, Greece, Slovenia, Estonia and Latvia have been the only countries to increase the role of taxation rates and regulations and to reduce the relative contribution that economic factors have played in the generation of the revenue collected. For all the other Member States, economic growth and structural change effect have been the drivers of environmental tax revenue variations [31-33].

A method of evaluating and adapting of the impact and the efficiency of environmental taxes, taking in account the budgetary criteria in the aspect of sufficiency terms of stability was defined and developed [34].

[35] examined appropriate design of efficient climate taxes on consumption of food by constructing a simple theoretical model and exemplifying the results using the examples of tomatoes and beef in Sweden. The theoretical results showed that, for the tax to be efficient, existing taxes on greenhouse gases should be considered when calculating the climate impact in order to avoid double taxation, and taxes should be differentiated between greenhouse gases, methane and nitrous oxide because of their differing climate impacts.

The effects of environmental taxes differ in EU countries, also environmental taxes systems are of different construction, and tax policies in this scope vary as well. $23 \mathrm{EU}$ countries belonging to OECD were analysed for 2016, on the basis of the Eurostat dataset. The study attempts to answer the question whether environmental taxes are an effective instrument for shaping environmental policy and whether they can become an important tool in the decision-making process at the government level. The results prove a positive relationship between environmental taxes and environmental performance in the case of one indicator (Share of renewable energy in gross final energy consumption) for others a negative link was reported. In the area of environmental performance, Pearson's linear correlation coefficients were determined between the shares of environmental tax, \% of total taxes, and the synthetic measure characterizing the environment performance in the respondents EU countries belonging to the OECD. It turns out that only in the case of one indicator (share of renewable energy in gross final energy consumption, \%) authors observe slight, positive relationship, which means that the increase of shares of environmental tax, \% of total taxes causes a decrease in the shares of renewable energy in gross final energy consumption [36].

Economists have rarely considered the implications of taxation systems for the agricultural sector. Management specialists and accountants have usually approached the issue from the perspective of how farmers and landowners can avoid it. Little has been written on the extent to which the special treatments that agriculture commonly receives in national tax systems impact on the sector and its performance. Tax concessions can act as forms of support to incomes and wealth accumulation, though the identification and quantification of this support present fundamental conceptual difficulties and practical problems. Taxes are often advocated as instruments of environmental policy, and these may have income implications. Concessions given by capital taxes, in particular, constrain structural adjustment. Differential tax treatments can also impact on patterns of international trade by distorting comparative advantage, as perceived by farm operators. Table 1. provides literature review of instruments in agriculture.

[42] focused on the environmental effectiveness of alternative agro-environmental policy reforms. Through reinstrumentation of domestic agricultural policies from market price supports to decoupled direct payments, agricultural policy and trade reforms can be used to reduce some adverse environmental effects associated with agriculture. However, targeted agro-environmental policies still play an important role in internalizing environment related agricultural 
Table 1. Instruments in agriculture - review.

\begin{tabular}{|c|c|c|}
\hline Authors & Article/study & Objective(s) \\
\hline$[37]$ & $\begin{array}{c}\text { The use of economic instruments in } \\
\text { environmental policies to mitigate diffuse } \\
\text { pollution from agriculture. }\end{array}$ & $\begin{array}{c}\text { Diffuse pollution from agriculture as a result of } \\
\text { the land use- fertilizer and pesticide taxes, use of } \\
\text { economic instruments - advantages, } \\
\text { disadvantages and assessment. }\end{array}$ \\
\hline
\end{tabular}

Key findings: The economic instruments have many advantages compared with the command-and control and/or voluntary agreement, and therefore their application should be enhanced and encouraged. - For a policy to mitigate the diffuse pollution from agriculture to be effective, the economic instruments, command-and control and voluntary agreement, need to be combined or incorporated in the same policy.

\begin{tabular}{|c|c|c|}
\hline$[38]$ & $\begin{array}{c}\text { Taxation concessions as instruments } \\
\text { of agricultural policy. }\end{array}$ & $\begin{array}{c}\text { Preferential treatment for agriculture -inventory } \\
\text { of tax treatments as instruments, compiled for the } \\
\text { OECD. }\end{array}$
\end{tabular}

Key findings: Special treatments for agriculture in general tax systems can be used as policy instruments. In many countries (including the UK) there is an established infrastructure that can be used in an economic delivery mechanism. Tax systems also contain much of the basic information needed to operate policies. Environmental policy, technology adoption and
the size distribution of firms.
Investigate the effects of emission taxes, uniform emission standards, and performance standards on the size distribution of firms.

Key findings: emission standards introduce regulatory asymmetries favouring small firms. On the contrary, emission taxes and performance standards reduce to a lower extent profits of larger firms but they do modify the optimal scale of firms. When the regulatory asymmetries created by emissions standards are taken into account, the profitability of emissions reducing technologies is higher under emission standards than under market-based instruments.

Assessment of policy instruments for pesticide use reduction in Europe; Learning from a systematic literature review.
Effectiveness of public and private policy instruments in terms of reducing pesticide use by farmers via a literature review of 78 articles.

Key findings: no specific instrument is guaranteed to reduce pesticide use. In particular, mixes of instruments, with varying degrees of authoritative force, applied at multiple scales with stakeholder collaboration were identified as beneficial to reducing farmer pesticide use. It is implied within the literature that instruments comprised of such characteristics aid reducing pesticide use due to facilitating consideration of heterogeneous farm and farmer characteristics.

\begin{tabular}{|c|c|c|}
\hline$[41]$ & $\begin{array}{c}\text { The revealed preferences of Baltic Sea } \\
\text { governments: Goals, policy instruments, and } \\
\text { implementation of nutrient abatement measures. }\end{array}$ & $\begin{array}{c}\text { Investigate the determinants of how } \\
\text { nutrient abatement measures are implemented by } \\
\text { countries in the agricultural sector of the Baltic } \\
\text { Sea region, through econometric analysis of a } \\
\text { cross-sectional data. }\end{array}$ \\
\hline $\begin{array}{c}\text { Key findings: no significant effect of income on implementation policy instruments, and hence there is no indication of equity with } \\
\text { respect to actual abatement efforts. The results suggest that 14 countries are more inclined to set goals and pay subsidies for } \\
\text { measures that reduce nitrogen and phosphorus. }\end{array}$ \\
\hline \multicolumn{2}{c}{}
\end{tabular}

externalities. The authors simulated government impact-neutral policy mixes by using Finnish data, and analysed what was the need for the increase in the government net support if one requires that, in spite of reduced production, farm income must remain unchanged after the readjustments of the input use. This alternative is called a farm revenue-neutral reform [42].

The problem of water regulation in agriculture was analysed in connection to the water framework directive by setting up and testing a simulation model based on the integration of a mathematical programming model at farm level and an optimal regulation model at the level of irrigation boards. The model allows quantifying water demand and optimal regulation from the policy maker's point of view. The optimal policy is a combination of pricing instruments related at the same time to crop mix, water consumption, and pollution. Transaction costs connected to policy implementation have to be weighted against the incentive benefits of volumetric pricing. Altogether, economic, social, and environmental issues have to be carefully considered in order to design suitable water policies $[43,44]$.

\section{Material and Methods}

The main research question was addressed to investigate, using a quantitative approach, the role and function of environmental indicators selected according the literature review [17, 20, 45, 46] namely flat rate, organic farming, ammonia emissions, energy taxes, implicit tax rate on energy, resource productivity, work productivity and income tax on financial and production indicators of Slovak agricultural sector based on 10 years national database, time period 2009-2018 collected by Radela company and environmental indicators collected 
by Eurostat and FADN. In order to identify and quantify the impact of variables was selected multiple regression analysis as the most suitable method and represented the main scientific method of the article. As additional scientific methods were selected correlation analysis and hierarchical agglomerative clustering method, in order to identify the position of Slovakia across EU Member States in two time periods 2009 and 2018 based on the environmental indicators.

\section{Multiple Regression Analysis Definition and Description of Variables}

The multiple regression equation is as follows in formula (1):

$$
\hat{Y}=b_{0}+b_{1} X_{1}+b_{2} X_{2}+\cdots b_{p} X_{p}+\varepsilon_{t}
$$

$\hat{Y}$ is the dependent variable, $X_{1}$ through $X_{p}$ are $\mathrm{p}$ distinct independent variables, $b_{0}$ is the value of $Y^{p}$ when all of the independent variables $\left(X_{1}\right.$ through $\left.X_{p}\right)$ are equal to zero, $b_{1}$ through $b_{p}$ are the estimated regression coefficients. Each regression coefficient represents the change in $\mathrm{Y}$ relative to a one unit change in the respective independent variable. $\varepsilon_{t}$ is random component.

Dependent variables definitions:

model 1: production indicator - total output/ total input model 2: financial indicator- ROE (Return on Equity) $=$ net income / equity

Definition of Independent variables for production model and financial model:

ETR: effective tax rate is the percentage of income actually paid by a company after taking into account tax breaks (including loopholes, deductions, exemptions, credits and preferential rates). Effective tax rate defined as income tax/earnings before tax in $\%$

org_farming: the indicator measures the share of total utilised agricultural area occupied by organic farming. Farming is recognised to be organic if it complies with Council Regulation (EC) No 834/2007, which has set up a comprehensive framework for the organic production of crops and livestock and for the labelling, processing and marketing of organic products, as well as for governing imports of organic products into the EU.

ammonia: this indicator tracks trends in anthropogenic atmospheric emissions of ammonia by agriculture, defined as \% of total emissions according EEA.

etax_paysec: the indicator measures the percentage of energy taxes that are raised against paying sectors as a proportion of the total amount of tax revenue raised from energy taxes.

itroe: implicit tax rate on energy. This indicator is defined as the ratio between energy tax revenues and final energy consumption calculated for a calendar year. Energy tax revenues are measured in euro (deflated) and the final energy consumption as toe (tonnes of oil equivalent). res_prod: resource productivity is gross domestic product (GDP) divided by domestic material consumption. It is defined as the annual quantity of raw materials extracted from the domestic territory of the focal economy, plus all physical imports minus all physical exports, defined in Purchasing Power Standard unit.

work_prod: work productivity defined as gross value added per worker.

FR: flat rate. Alternative approach - formula (2) is the combination of economic and environmental objective criteria [47]:

$$
\begin{gathered}
F R \times\left[\frac{2}{3} \times\left(\frac{2}{3} G D P / c a p+\frac{G V A}{A W U}\right)\right]+\frac{1}{3} \times\left(\frac{1}{3} L F A\right. \\
\left.+\frac{1}{3} \text { Permanent Grassland }+\frac{1}{3} \text { Natura }_{2000} \text { area }\right)
\end{gathered}
$$

defined as:

- economic criteria related to agriculture, AWU (annual working unit) and GVA/AWU (gross value added per AWU): comparison to the EU average with the Member States with higher GVA/ AWU receiving higher direct payments/ha, direct payments/ beneficiaries. These criteria would reflect differences in productivity in the agricultural sectors of Member States with agricultural factor income/ AWU and share direct payment of farm income [47].

- general economic criteria, PPS (purchasing power standard) and GDP/cap: an index is used for the adjustment in relation to the EU average with the Member States with higher GDP/capita (expressed in PPS) receiving higher direct payments/ha. These criteria would reflect disparities in the costs of living between Member States [47].

- for the environmental criteria, areas in less favoured areas (LFA), Natura 2000 zones and permanent pasture: The index compares the share of the relevant area in the Member State's total utilised agricultural area (UAA) to the EU average. Thus, Member States with a higher share of these types of areas get higher direct payments/ha [47].

Using these variables, the following 2 models of Slovak agriculture were defined as formula (3) and formula (4):

$$
\begin{gathered}
\text { OUTPUT/INPUT }=b_{0}+b_{1} \text { org_farming } \\
+b_{2} \text { ammonia }+b_{3} \text { etax_paysec }+b_{4} \text { itroe } \\
+b_{5} \text { res_prod }+b_{6} \text { Work_prod }+b_{7} F R+b_{8} E T R+\varepsilon_{t}
\end{gathered}
$$

$$
\begin{gathered}
R O E=b_{0}+b_{1} \text { org_fa*ming }+b_{2} \text { ammonia } \\
b_{3} \text { etax_paysec }+b_{4} \text { itroe }+b_{5} \text { res_prod } \\
+b_{6} \text { work_prod }+b_{7} F R+b_{8} E T R+\varepsilon_{t}
\end{gathered}
$$

The enforcement of policy instruments is usually a shared responsibility of different governments at different levels. There are requirements from the EU 
with respect to the monitoring and control of measures. The selection of these variables was influenced by following reasons: The agricultural analysis used to specialise to examine production and effectivity of resources. The agricultural sector performance depends on the tax system that affects the profitability. The selected variables represented environmental, production and taxation characteristics of Slovak agriculture sector.

The article defined main hypothesis:

H1: Production and financial indicators were dependent on the same variables.

For this purpose, the following independent hypotheses were statistically tested:

Production Indicator - H0: The energy tax did not have a significant influence on the output/input variable in a multiple regression analysis.

Financial Indicator- H0: The energy tax did not have a significant influence on the ROE in a multiple regression analysis.

The next analysis applied in our research was correlation analysis. The correlation coefficient is a statistical measure that calculates the strength of the relationship between the relative movements of two variables. The value range between -1.0 and 1.0. A calculated number greater than 1.0 or less than -1.0 means that there was an error in the correlation measurement. A correlation of -1.0 shows a perfect negative correlation, while a correlation of 1.0 shows a perfect positive correlation. A correlation of 0.0 shows no relationship between the movement of the two variables.

The final part of the analysis was clustering based on the Ward's Hierarchical Agglomerative Clustering Method. The clusters were identified according the same independent variables as to regression analysis. Ward's is the only one among the agglomerative clustering methods that is based on a classical sum-of-squares criterion, producing groups that minimize within-group dispersion at each binary fusion. In addition, Ward's method is interesting because it looks for clusters in multivariate Euclidean space.

\section{Results and Discussion}

\section{The Multiple Regression Analysis Results}

The first step of analysis was to verify the statistical significance of individual variables. In this case, the statistical significance of each variable was tested via the summary command. As non-significant variables were identified: org_farming, ammonia, itroe and res_prod. Then, the statistically significant models were subsequently tested.

Table 2 and Table 3 contain the tests results.

The first statistically significant determinant was flat rate indicator, which synthesized economic and environmental criteria in the process of settlement the EU Common Agricultural Policy. The coefficient belonging to this determinant was $-4.349 \mathrm{e}-06$ that represented a negative impact on the agricultural production indicator defined as output/input. The negative impact of flat rate indicator was investigated also in the case of financial model. If the flat rate would be 1 unit higher the ROE indicator would decrease by 0.0005363 with a probability of $90 \%$.

A wide range of existing instruments under the second pillar of the Common Agricultural Policy has been simplified to focus on promoting competitiveness,

Table 2. Multiple regression analysis results - production model.

\begin{tabular}{|c|c|c|c|c|c|}
\hline & Estimate & Std. Error & $\mathrm{t}$ value & $\operatorname{Pr}(>|t|)$ & \\
\hline (Intercept) & $8.977 \mathrm{e}-01$ & $2.234 \mathrm{e}-02$ & 40.176 & $1.8 \mathrm{e}-07$ & $* * *$ \\
\hline FR & $-4.349 \mathrm{e}-06$ & $1.784 \mathrm{e}-06$ & -2.438 & 0.05881 & . \\
\hline etax_paysec & $-1.458 \mathrm{e}-02$ & $4.613 \mathrm{e}-03$ & -3.161 & 0.02507 & * \\
\hline work_prod & $8.790 \mathrm{e}-06$ & $6.760 \mathrm{e}-07$ & 13.003 & $4.8 \mathrm{e}-05$ & $* * *$ \\
\hline ETR & $9.918 \mathrm{e}-03$ & $2.102 \mathrm{e}-03$ & 4.718 & 0.00525 & $* *$ \\
\hline \multicolumn{6}{|c|}{ Signif. codes: 0 ‘***’ 0.001 '**’ $0.01^{\prime *} * 0.05$ ', 0.1 ' ' 1} \\
\hline \multicolumn{6}{|c|}{ statistically significant production model tests results } \\
\hline \multicolumn{6}{|c|}{ autocorrelation: Durbin-Watson test $\mathrm{p}$-value $>\alpha$} \\
\hline \multicolumn{6}{|c|}{ heteroscedasticity: studentized Breusch-Pagan test $\mathrm{p}$-value $>\alpha$} \\
\hline
\end{tabular}

If we looked at F-statistic we would see that $\mathrm{p}$-value $<\alpha(0.0001289<0.05)$, production model was statistically significant. The statistical significance was also confirmed by the reset test where: $p$-value $>\alpha(0.3916>0.05)$. Jacque Bera test confirmed normality of residues with $\mathrm{p}$-value $=0.687$. According to the coefficient of determination $R^{2}$ is stated that the production model explained $96.95 \%$ of the total variability. In this case, $96.95 \%$ correctly explained the explanatory variable production indicator output/input and the rest $3.05 \%$ was a random component. 
Table 3. Multiple regression analysis results - financial model.

\begin{tabular}{|c|c|c|c|c|c|}
\hline & Estimate & Std. Error & t value & $\operatorname{Pr}(>|t|)$ & \\
\hline (Intercept) & $-1.611 \mathrm{e}+01$ & $2.841 \mathrm{e}+00$ & -5.671 & 0.00237 & $* *$ \\
\hline FR & $-5.363 \mathrm{e}-04$ & $2.269 \mathrm{e}-04$ & -2.364 & 0.06445 & . \\
\hline etax_paysec & $-2.375 \mathrm{e}+00$ & $5.866 \mathrm{e}-01$ & -4.048 & 0.00984 & $* *$ \\
\hline work_prod & $1.154 \mathrm{e}-03$ & $8.597 \mathrm{e}-05$ & 13.423 & $4.11 \mathrm{e}-05$ & $* * *$ \\
\hline ETR & $1.287 \mathrm{e}+00$ & $2.674 \mathrm{e}-01$ & 4.812 & 0.00483 & $* *$ \\
\hline \multicolumn{6}{|c|}{ Signif. codes: 0 ‘***’ 0.001 '**’ 0.01 '*’ 0.05 ', 0.1 ' ' 1} \\
\hline \multicolumn{6}{|c|}{ statistically significant financial model tests results } \\
\hline \multicolumn{6}{|c|}{ autocorrelation: Durbin-Watson test p-value $>\alpha$} \\
\hline \multicolumn{6}{|c|}{ heteroscedasticity: studentized Breusch-Pagan test $p$-value $>\alpha$} \\
\hline \multicolumn{6}{|c|}{ multicollinearity: vif command $<3$ for all variables } \\
\hline
\end{tabular}

Financial model was statistically significant according F-statistic with p-value $<\alpha(0.0001337<0.05)$. The statistical significance was also confirmed by the reset test where: $p$-value $>\alpha(0.3916>0.05)$. Jacque Bera test confirmed normality of residues with p-value $=0.4618$. According to the coefficient of determination $R^{2}$ is stated that the financial model explained $98.28 \%$ of the total variability. In this case, $98.28 \%$ correctly explained the explanatory variable ROE indicator and the rest $1.72 \%$ was a random component.

innovation, knowledge-based agriculture, young farmers at the start of business, sustainable management of natural resources and balanced territorial development. However, greening through Pillar 2 is not a panacea, as the recent criticisms of Pillar 2 agri-environmental measures by the European Court of Auditors made clear. Part of the problem is that agri-environmental measures are simplified policies in which farmers are offered a flat-rate payment in return for undertaking management actions which are presumed to have positive impacts on one or more environmental variables.

Analysis of the impact of greening the CAP payments identified very small impact on the beef and sheep farms in Scotland. This was expected as the target of the greening measures are largely lowland arable farms. This agrees with other studies who have argued that there will be very little impact of greening on EU agricultural production with little to no impact on livestock production [48]. The impact of crop diversification and permanent grassland measures will be negligible as most of farmers already meet these criteria. [49] argue that the most effective measure would be the ecological focus area criteria, where changes will be seen in the levels of production and GHG emissions in the EU.

European Commission identified the impact of redistribution of direct payments on farm income FADN data [50]. For the impact assessment at farms' level it was considered that the entire country is one single region. An 'EU flat rate' would lead to massive changes in farmers' incomes in many Member States in both directions. The FADN analysis shows that there would be an increase of $8.6 \%$ of farm income in EU-12 and a decrease of $2.1 \%$ in EU-15 compared to the baseline level in 2020. The most affected countries would be DK, GR, BE, SL, DE, IT and CY (between -8 and $-5 \%$ ), while farm income in EE, LT, LV will benefit the most (by $45 \%, 26 \%$ and $53 \%$ respectively) and also PT, RO and SVK to a lower extent (between $13 \%$ and $16 \%$ ). The article results did not confirm the impact of flat rate on Slovak agriculture from financial a production point of view.

Energy tax by paying sector represented second statistically significant variable of financial and production models. If the percentage of energy tax in agriculture increase by $1 \%$ production would decreased by 0.01458 with a probability of $95 \%$ and ROE indicator would decrease by 2.375 with a probability of $99 \%$. The most statistically significant variable was work productivity, with positive impact on production and ROE indicators of Slovak agriculture. If the gross value added per worker would be 1 unit higher the production variable would increase by 0.00000879 and ROE would rise by 0.001154 , both variables with a probability of $99 \%$.

Effective tax rate was considered as the last statistically significant variable, with positive impact on production and ROE indicator. If ETR would be $1 \%$ higher production indicator would increase by 0.009918 and ROE would be 1.287 higher, with a probability of $99 \%$. The results were influenced by the rules of Slovakia income taxation mainly exceptions, rules of depreciation and structure of farmers with different financial conditions. This variable represented the national characteristics of tax burden, which differ from the statutory tax rate.

The functions of agricultural sector include three dimensions - economic, social, environmental, which are closely connected with the conception of sustainable 
Table 4. Correlation analysis of dependent and statistically significant independent variables.

\begin{tabular}{|c|c|c|c|c|c|c|}
\hline & ROE & OUTPUT/INPUT & ETR & FR & etax_paysec & work_prod \\
\hline ROE & 1 & & & & & \\
\hline OUTPUT/INPUT & 0,998 & 1 & & & & \\
\hline ETR & 0,261 & 0,258 & 1 & & & \\
\hline FR & $-0,426$ & $-0,447$ & 0,086 & 1 & & 1 \\
\hline etax_paysec & $-0,495$ & $-0,543$ & $-0,075$ & 0,444 & 1 & \\
\hline work_prod & 0,926 & 0,938 & 0,013 & $-0,406$ & $-0,680$ & 1 \\
\hline
\end{tabular}

development [51, 52]. These three dimensions of Slovak agriculture were investigated as the analysis results. The relationship of the variables was defined through the correlation analysis. The additional research method supported the results of multiple regression analysis, in Table 4. A high positive correlation was identified in the case of work productivity and output/input indicator and ROE indicator. A slight negative correlation was discovered between flat rate, energy tax and dependent variables ROE and output/input.

The economic dimension of sustainable taxation system is oriented towards the economic growth, to which the agricultural business as well as stability and survival of agricultural business contribute greatly. Environmental taxes are now commonly known to constitute a cost-effective corrective approach contributing to the development and use of clean technologies. Environmental taxes can be applied to most environmental problems - climate change mitigation being a clear candidate - as part of a wider green tax reform with distributional and/or revenue objectives $[53,54]$.

In order to identify the position of Slovakia agriculture (Fig. 1.) across the EU Member States hierarchical agglomerative cluster analysis was used based on environmental indicators.

The cluster analysis identified 4 homogenous clusters of EU Member States. Slovakia was a member of first cluster with Czech Republic, Austria, Greece, Sweden, Finland and Estonia.

European union agriculture 2009 dendrogram

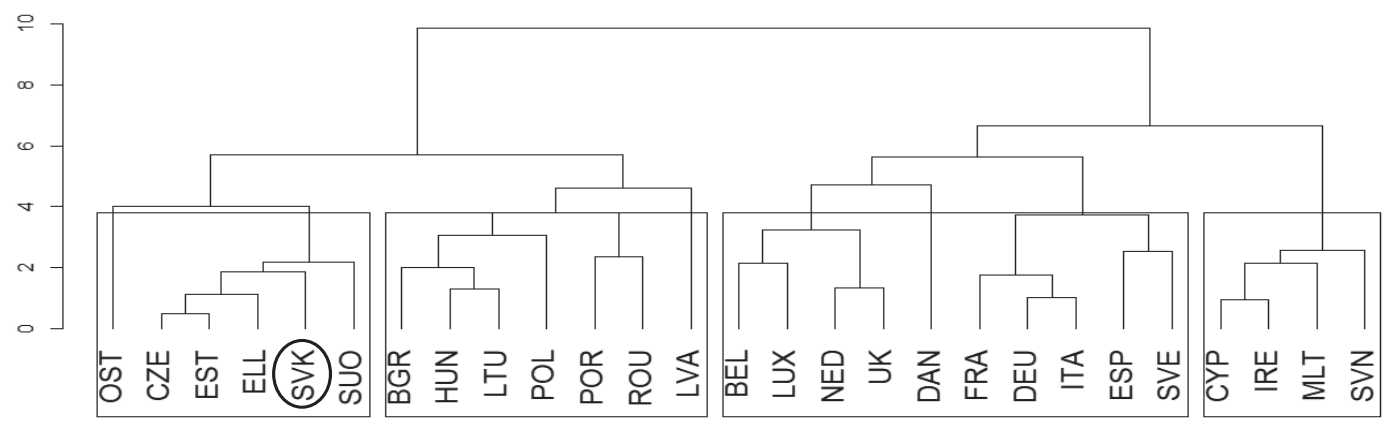

Fig. 1. Dendrogram of EU Member States based on 2009 environmental indicators.

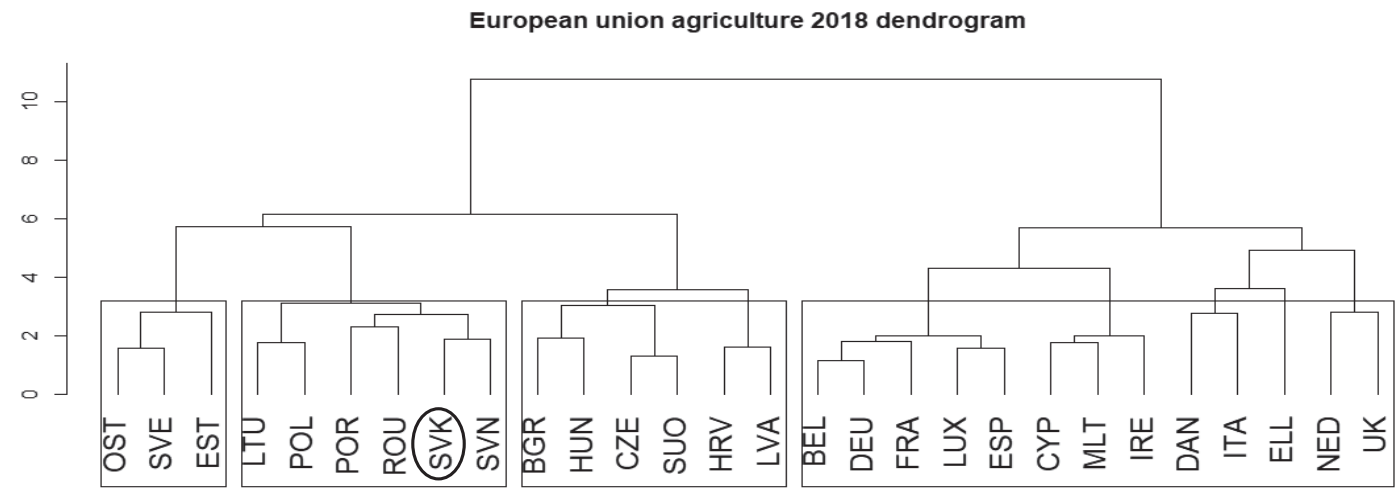

Fig. 2. Dendrogram of EU Member States based on 2018 environmental indicators. 
Table 5. Main clusters characteristics of environmental indicators.

\begin{tabular}{|c|c|c|c|c|c|c|}
\hline Clusters & \multicolumn{3}{|c|}{2009 Clusters characteristics } & \multicolumn{3}{|c|}{2018 Clusters characteristics } \\
\hline Cluster 1 & FR & etax_paysec & work_prod & FR & etax_paysec & work_prod \\
\hline Mean & 5591 & 4 & 13975 & 44782 & 5 & 25277 \\
\hline Standard Error & 2121 & 1 & 2785 & 788 & 1 & 3805 \\
\hline Median & 4419 & 4 & 15403 & 44000 & 4 & 28480 \\
\hline ST DEV & 5194 & 2 & 6822 & 1364 & 2 & 6590 \\
\hline Sample Variance & 26982423 & 3 & 46533588 & 1861292 & 6 & 43432492 \\
\hline Kurtosis & 3 & 0 & 0 & - & - & - \\
\hline Skewness & 2 & 0 & -1 & 2 & 2 & -2 \\
\hline Range & 14066 & 5 & 18025 & 2369 & 4 & 11956 \\
\hline Minimum & 1295 & 1 & 2453 & 43988 & 4 & 17697 \\
\hline Maximum & 15361 & 6 & 20478 & 46357 & 8 & 29653 \\
\hline Sum & 33544 & 21 & 83852 & 134345 & 16 & 75830 \\
\hline Count & 6 & 6 & 6 & 3 & 3 & 3 \\
\hline Con. Lev.(95,0\%) & 5451 & 2 & 7159 & 3389 & 6 & 16371 \\
\hline Cluster 2 & FR & etax_paysec & work_prod & FR & etax_paysec & work_prod \\
\hline Mean & 4728 & 5 & 6133 & 39067 & 3 & 11332 \\
\hline Standard Error & 1508 & 1 & 926 & 3847 & 1 & 2647 \\
\hline Median & 4255 & 5 & 5977 & 43966 & 3 & 8442 \\
\hline ST DEV & 3990 & 3 & 2451 & 9423 & 2 & 6485 \\
\hline Sample Variance & 15919590 & 8 & 6005278 & 88787819 & 4 & 42049401 \\
\hline Kurtosis & 0 & -1 & -1 & 2 & -1 & 2 \\
\hline Skewness & 1 & 0 & 1 & -2 & 0 & 2 \\
\hline Range & 10846 & 8 & 6902 & 24319 & 6 & 16926 \\
\hline Minimum & 864 & 1 & 3051 & 21582 & 0 & 6336 \\
\hline Maximum & 11710 & 9 & 9953 & 45901 & 6 & 23262 \\
\hline Sum & 33096 & 35 & 42928 & 234403 & 17 & 67990 \\
\hline Count & 7 & 7 & 7 & 6 & 6 & 6 \\
\hline Con. Lev.(95,0\%) & 3690 & 3 & 2266 & 9889 & 2 & 6805 \\
\hline Cluster 3 & FR & etax_paysec & work_prod & FR & etax_paysec & work_prod \\
\hline Mean & 5334 & 2 & 28285 & 34 & 5 & 18561 \\
\hline Standard Error & 1631 & 0 & 2634 & 8 & 1 & 3800 \\
\hline Median & 5231 & 2 & 25643 & 41 & 5 & 19066 \\
\hline ST DEV & 5158 & 1 & 8330 & 19 & 2 & 9309 \\
\hline Sample Variance & 26605666 & 1 & 69383201 & 364 & 5 & 86651253 \\
\hline Kurtosis & 0 & 0 & -1 & 1 & 0 & -2 \\
\hline Skewness & 1 & -1 & 1 & -1 & 0 & 0 \\
\hline Range & 15169 & 3 & 24805 & 53 & 6 & 23140 \\
\hline Minimum & 192 & 0 & 18734 & 0 & 2 & 8116 \\
\hline Maximum & 15361 & 3 & 43539 & 53 & 9 & 31256 \\
\hline Sum & 53337 & 19 & 282852 & 202 & 31 & 111367 \\
\hline
\end{tabular}


Table 5. Continued.

\begin{tabular}{|c|c|c|c|c|c|c|}
\hline Count & 10 & 10 & 10 & 6 & 6 & 6 \\
\hline Con. Lev.(95,0\%) & 3690 & 1 & 5959 & 20 & 2 & 9769 \\
\hline Cluster 4 & FR & etax_paysec & work_prod & FR & etax_paysec & work_prod \\
\hline Mean & 558 & 1 & 8786 & 17922 & 2 & 34465 \\
\hline Standard Error & 247 & 0 & 2191 & 4764 & 0 & 4615 \\
\hline Median & 541 & 1 & 8069 & 19450 & 2 & 35005 \\
\hline ST DEV & 493 & 1 & 4381 & 17178 & 2 & 16639 \\
\hline Sample Variance & 243225 & 1 & 19197062 & 295094636 & 3 & 276842409 \\
\hline Kurtosis & -4 & -1 & 1 & -1 & 2 & -1 \\
\hline Skewness & 0 & 1 & 1 & 0 & 1 & 0 \\
\hline Range & 1044 & 2 & 10423 & 44075 & 6 & 49705 \\
\hline Minimum & 52 & 0 & 4291 & 0 & 0 & 9996 \\
\hline Maximum & 1096 & 2 & 14714 & 44075 & 6 & 59701 \\
\hline Sum & 2230 & 3 & 35143 & 232982 & 28 & 448050 \\
\hline Count & 4 & 4 & 4 & 13 & 13 & 13 \\
\hline Con. Lev.(95,0\%) & 785 & 2 & 6972 & 10381 & 1 & 10055 \\
\hline
\end{tabular}

The position of Slovak agriculture changed in 2018 (Fig. 2.), according the environmental indicators namely flat rate indicator, energy tax paid by agricultural sector and work productivity. Table 5 contains the main characteristics of environmental indicators across identified clusters. Slovak agriculture was in the second cluster with Lithuania, Poland, Portugal, Romania and Slovenia. The 13 old Member States defined the biggest cluster 4 according implemented environmental reforms and higher work productivity per worker.

The hierarchical cluster analysis was used by [55] and European countries were divided in four homogeneous groups, [55] analysed two time periods 2000 and 2008. The cluster analysis showed that, within a decade, the level of attention to the environment and the use of fiscal instruments for environmental policy was very differentiated among countries. Despite a major balance between environmental taxation and other taxes was evident in countries in which environmental tax reforms was applied, the level of environmental taxation was still low.

\section{Conclusions}

Environmental taxation has been growingly seen as an effective economic instrument to create incentives in favour of cleaner production and consumption habits. There is an important discussion around the economic and environmental effects of this economic instrument, which was supported through the literature review notably in agriculture sector.
Results of the analysis pointed to the statistically significant determinants of Slovak agriculture based on 10 years' data provided by Radela company and environmental indicators defined according Eurostat and FADN databases. Main scientific question was answered by rejecting both independent hypotheses based on data. The analysis realised by the multiple regression and correlation coefficient confirmed main hypothesis that production and financial indicators were dependent on the same variables.

The first statistically significant determinant was flat rate indicator, which synthesized economic and environmental criteria. The coefficient belonging to this determinant was $-4.349 \mathrm{e}-06$ that represented a negative impact on the agricultural production indicator defined as output/input. The negative impact of flat rate indicator was investigated also in the case of financial model. If the flat rate would be 1 unit higher the ROE indicator would decrease by 0.0005363 with a probability of $90 \%$. This indicator represents an alternative approach is the combination of economic and environmental objective criteria. The usage of flat rate instrument is widely discussed by economists. Energy tax by paying sector represented second statistically significant variable of financial and production models. If the percentage of energy tax in agriculture increase by $1 \%$ production would decreased by 0.01458 with a probability of $95 \%$ and ROE indicator would decreas e by 2.375 with a probability of $99 \%$. Environmental protection, based on energy taxes, affected less the agriculture production than the profitability in the agriculture sector. However, this should be worth 
it to us. The most statistically significant variable was work productivity, with positive impact on production and ROE indicators. Effective tax rate was considered as the last statistically significant variable. This variable represented the national characteristics of tax burden, which differ from the statutory tax rate.

In order to identify the position of Slovakia agriculture across the EU Member States was used hierarchical agglomerative cluster analysis. The cluster analysis of 2009 year identified 4 homogenous clusters of EU Member States. Slovakia was a member of first cluster with Czech Republic, Austria, Greece, Sweden, Finland and Estonia. The position of Slovak agriculture changed in 2018, according the environmental indicators. Slovak agriculture was in the second cluster with Lithuania, Poland, Portugal, Romania and Slovenia. The 13 old Member States defined the biggest cluster according implemented environmental reforms and higher work productivity per worker.

Taxes can directly address the failure of markets to take environmental impacts into account by incorporating these impacts into prices. Environmental pricing through taxation leaves consumers and businesses the flexibility to determine how best to reduce their environmental "footprint". This enables lowest-cost solutions, provides an incentive for innovation and minimises the need for government to attempt to "pick winners". Clear communication is critical to public acceptance of environmental taxation. Environmental taxes may need to be combined with other policy instruments to address certain issues.

\section{Acknowledgements}

This research was supported by VEGA project No. 1/0430/19 Investment decision-making of investors in the context of effective corporate taxation.

\section{Conflict of Interest}

The authors declare no conflict of interest.

\section{References}

1. KOSONEN K., NICODÈME G. The role of fiscal instruments in environmental policy, 2009.

2. AMBEC S., COHEN M.A., ELGIE S., LANOIE P. The Porter hypothesis at 20: can environmental regulation enhance innovation and competitiveness?. Review of environmental economics and policy, 7 (1), 2, 2013.

3. FREIRE-GONZÁLEZ J. Environmental taxation and the double dividend hypothesis in CGE modelling literature: A critical review. Journal of Policy Modeling, 40 (1), 194, 2018.

4. BÖCKER T., FINGER R. European pesticide tax schemes in comparison: An analysis of experiences and developments. Sustainability, 8 (4), 378, 2016.
5. ANDREONI V. Environmental taxes: Drivers behind the revenue collected. Journal of cleaner production, 221, 17, 2019.

6. ANDRETTA A., D'ADDATO F., SERRANOBERNARDO F., ZAMORANO M., BONOLI A. Environmental taxes to promote the eu circular economy's strategy: Spain vs. Italy. Environmental Engineering and Management Journal, 17 (10), 2307, 2018.

7. MAXIM M., ZANDER K. Can a green tax reform entail employment double dividend in European and non-European countries? A survey of the empirical evidence. International Journal of Energy Economics and Policy, 9 (3), 218, 2019.

8. BIANCO A. Green Jobs and Policy Measures for a sustainable agriculture. Agriculture and agricultural science procedia, 8, 346, 2016.

9. JAEGER W.K. Environmental taxation and the double dividend. Online Encyclopedia of Ecological Economics (OEEE). Available online: http://www. ecoeco. org/ education_encyclopedia.php, (accessed on 7 July 2020).

10. ROSIEK J. The impact of environmental tax policy on sustainable development of the eu economies. Dea approach. In $11^{\text {th }}$ international conference of asecu "Openness, innovation, efficiency and democratization as preconditions for economic development", 233, 2015.

11. CASTIGLIONE C., INFANTE D., MINERVINI M.T., SMIRNOVA J. Environmental taxation in Europe: What does it depend on?. Cogent Economics \& Finance, 2 (1), 967362, 2014.

12. CHIROLEU-ASSOULINE M., FODHA M. From regressive pollution taxes to progressive environmental tax reforms. European Economic Review, 69, 126, 2014.

13. KURTINAITYTĖ-VENEDIKTOVIENE D., PEREIRA P., ČERNIAUSKAS G. Environmental taxes in Northern Europe. The recent evolution and current status in the Baltic countries. Socialinių mokslų studijos, (6), 331, 2014.

14. KWILINSKI A., RUZHYTSKYI I., PATLACHUK V., KAMINSKA B. Environmental Taxes as a Condition of Business Responsibility in the Conditions of Sustainable Development. Journal of Legal, Ethical and Regulatory Issues, 2019.

15. HOERNER J.A., BOSQUET B. Environmental tax reform: the European experience. Center for a Sustainable Economy, Washington, DC, 2001.

16. BEUERMANN C., SANTARIUS T. Ecological tax reform in Germany: handling two hot potatoes at the same time. Energy Policy, 34 (8), 917, 2006.

17. BESUSPARIENE E. Singularity of sustainable taxation in agriculture. In International scientific conference RURAL DEVELOPMENT 2017, 909, 2017.

18. BAILEY I. European environmental taxes and charges: economic theory and policy practice. Applied Geography, 22 (3), 235, 2002.

19. ANDREI J., MIEILA M., POPESCU G.H., NICA E., CRISTINA M. (2016). The impact and determinants of environmental taxation on economic growth communities in Romania. Energies, 9 (11), 902, 2016.

20. RECANATI F., MAUGHAN C., PEDROTTI M., DEMBSKA K., ANTONELLI M. Assessing the role of CAP for more sustainable and healthier food systems in Europe: A literature review. Science of the Total Environment, 653, 908, 2019.

21. CZYZEWSKI B., MATUSZCZAK A., POLCYN J., SMĘDZIK-AMBROZY K., STANISZEWSKI J. Deadweight loss in environmental policy: The case of 
the European Union member states. Journal of Cleaner Production, 121064, 2020.

22. BACHEV H. A holistic approach for assessing the system of governance of agrarian sustainability. Available at SSRN 2831709, 2016.

23. BACHEV H., TERZIEV D.A study on agrarian sustainability impact of governance modes in Bulgaria. Journal of Applied Economic Sciences, 13 (1), 2018.

24. HIMICS M., FELLMANN T., BARREIRO-HURLÉ J., WITZKE H.P., DOMÍNGUEZ I.P., JANSSON T., WEISS F. Does the current trade liberalization agenda contribute to greenhouse gas emission mitigation in agriculture?. Food policy, 76, 120, 2018.

25. WILLIAMS R.C. Environmental taxation, No. w22303. National Bureau of Economic Research, 2016.

26. WITHANA S., TEN BRINK P., FRANCKX L., HIRSCHNITZ-GARBERS M., MAYERES I., OOSTERHUIS F., PORSCH L. Study supporting the phasing out of environmentally harmful subsidies. A report by the Institute for European Environmental Policy (IEEP), Institute for Environmental Studies - Vrije Universiteit (IVM), Ecologic Institute and VITO for the European Commission - DG Environment. Final Report. Brussels. 2012.

27. JORDAN A., WURZEL R., ZITO A.R., BRÜCKNER L. European governance and the transfer of 'new'environmental policy instruments (NEPIs) in the European Union. Public Administration, 81 (3), 555, 2003.

28. HELMING J., KUHLMAN T. Impact of a combined meat tax and vegetable protein subsidy on European agriculture, No. 716-2016-48668, 2015.

29. VAN DER VEEN H.B., VAN DER MEULEN H.A.B., VAN BOMMEL K.H.M., DOORNEWEERT R.B. Exploring agricultural taxation in Europe. LEI, 2007.

30. MILLER S. Tax policies, agriculture and the environment, No. 1099-2016-89543, 3, 2015.

31. MENDONÇA R., ROEBELING P., MARTINS F., FIDÉLIS T., TEOTÓNIO C., ALVES H., ROCHA J. Assessing economic instruments to steer urban residential sprawl, using a hedonic pricing simulation modelling approach. Land Use Policy, 92, 104458, 2020.

32. MØLLER N.F. Energy demand, substitution and environmental taxation: An econometric analysis of eight subsectors of the Danish economy. Energy Economics, 61, 97, 2017.

33. PALM V., LARSSON M. Economic instruments and the environmental accounts. Ecological economics, 61 (4), 684, 2007.

34. PICIU G.C., TRICĂ C.L. Assessing the impact and effectiveness of environmental taxes. Procedia Economics and Finance, 3, 728, 2012.

35. GREN M., MOBERG E., SÄLL S., RÖÖS E. Design of a climate tax on food consumption: examples of tomatoes and beef in Sweden. Journal of cleaner production, 211, 1576, 2019.

36. ZIOLO M., BAK I., CHEBA K. Environmental taxes-how public policy makers can use them in the decision-making process?. Procedia Computer Science, 159, 2216, 2019.

37. AHODO K., SVATONOVA T. The use of economic instruments in environmental policies to mitigate diffuse pollution from agriculture. Agricultural Economics, 60 (2), 74, 2014

38. HILL B., BLANDFORD D. Taxation concessions as instruments of agricultural policy, No. 349-2016-17918, 2007.
39. CORIA J., KYRIAKOPOULOU E. Environmental policy, technology adoption and the size distribution of firms. Energy Economics, 72, 470, 2018.

40. LEE R., DEN UYL R., RUNHAAR H. Assessment of policy instruments for pesticide use reduction in Europe; Learning from a systematic literature review. Crop Protection, 104929, 2019.

41. ELOFSSON K., VON BRÖMSSEN C. The revealed preferences of Baltic Sea governments: Goals, policy instruments, and implementation of nutrient abatement measures. Marine pollution bulletin, 118 (1-2), 188, 2017.

42. LANKOSKI J., OLLIKAINEN M. The environmental effectiveness of alternative agri-environmental policy reforms: theoretical and empirical analysis, 1999.

43. BAZZANI G.M., Di PASQUALE S., GALLERANI V., VIAGGI D. Irrigated agriculture in Italy and water regulation under the European Union Water Framework Directive. Water resources research, 40 (7), 2004.

44. SKEVAS T. Evaluating alternative policies to reduce pesticide groundwater pollution in Dutch arable farming. Journal of Environmental Planning and Management, 63 (4), 733, 2020.

45. RAPANOS V.T. Environmental taxation in a dualistic economy. Environment and Development Economics, 12 (1), 73, 2007.

46. WATKINS E., TEN BRINCK P., WITHANA S., RUSSI D., ILLES A., MUTAFOGLU K., PEDERSEN A.B. Capacity building, programmatic development and communication in the field of environmental taxation and budgetary reform, 2017.

47. EC-EUROPEAN COMMISSION. CAP Towards 2020 Impact Assessment: Greening-Results of Partial Analysis on Farm Income using FADN. EC, Brussels, 2011.

48. AHMADI B.V., SHRESTHA S., THOMSON S.G., BARNES A.P., STOTT A. W. Impacts of greening measures and flat rate regional payments of the Common Agricultural Policy on Scottish beef and sheep farms. Journal of Agricultural Science, 153 (4), 676, 2015.

49. VATN A., KROGH E., GUNDERSEN F., VEDELD P. Environmental taxes and politics -the dispute over nitrogen taxes in agriculture. European Environment, 12 (4), 224, 2002.

50. TEN BRINK P., MAZZA L. Reforming environmental taxes and harmful subsidies: challenges and opportunities. Institute for European Environmental Policy, Brussels, 2013.

51. RADULESCU M., SINISI C.I., POPESCU C., IACOB S.E., POPESCU L. environmental tax policy in Romania in the context of the EU: Double dividend theory. Sustainability, 9 (11), 1986, 2017.

52. FALLAN E., FALLAN L. Corporate tax behaviour and environmental disclosure: Strategic trade-offs across elements of CSR?. Scandinavian Journal of Management, 35 (3), 101042, 2019.

53. LABEAGA J.M., LABANDEIRA X. Economics of Environmental Taxes and Green Tax Reforms, 2020.

54. LABANDEIRA X., LABEAGA J.M., LÓPEZ-OTERO $X$. New Green Tax Reforms: Ex-Ante Assessments for Spain. Sustainability, 11 (20), 5640, 2019.

55. ARBOLINO R., ROMANO O. A methodological approach for assessing policies: The case of the Environmental Tax Reform at European level. Procedia Economics and Finance, 17, 202, 2014. 